\title{
Characterization of $\alpha$-L-Arabinofuranosidase (AbfA) Variant (Q46R; D205E; K285E) Biochemical Properties and in Silico Study on the Effect of Mutation to Its Structure
}

\author{
Ratna Melinda, Purkan, Handoko Darmokoesoemo, and N. N. T. Puspaningsih
}

\begin{abstract}
This study aimed to determine the biochemical properties of the AbfA variant (Q46R; D205E; K285E) also the correlation between change in biochemical properties and its tertiary structure modification. The enzyme expressed in $E$. coli BL21 (DE3)/ pBM5abf variant was partially purified by heat treatment for 1 hour at $70^{\circ} \mathrm{C}$. The partially purified enzyme was characterized for its biochemical properties. Protein tertiary structure model was built by homology modeling method using Geobacillus stearothermophilus T-6 a-L-arabinofuranosidase crystal structure (PDB: 1PZ3) as template. The protein structure model then subjected for in silico study. Partial purification showed an increase of purity by 17.60 fold. The partially purified enzyme showed optimum activity towards p-nitrophenyl- $\alpha$-L-arabinofuranoside (pNPA) at pH 7 and $70^{\circ} \mathrm{C}$ AbfA variant (Q46R; D205E; K285E) was stable for 24 hours at pH 6-9 (at $\left.4^{\circ} \mathrm{C}\right)$ and lost almost $70 \%$ of its activity on 16 hours incubation at $70^{\circ} \mathrm{C}$. Compared to its wildtype, AbfA variant (Q46R; D205E; K285E) showed decrease on thermostability. Superimpose of AbfA variant (Q46R; D205E; K285E) to its wildtype showed RMSD 0.05 . Tertiary structure assessment showed that mutations caused reduction of 3 Hydrogen bonds and 5 Van der Waals interactions also formation of 1 salt bridge and 1 weak electrostatic interaction. In silico analysis of AbfA variant (Q46R; D205E; K285E) protein model revealed that the decrease on thermostability was related to the reduction of some non covalent interactions especially Hydrogen bonds and Van der Waals interaction, due to modification in AbfA variant (Q46R; D205E; K205E) structure.
\end{abstract}

Index Terms-Biochemical properties, $\alpha$-L-arabinofuranosidase (AbfA), in silico, non covalent interaction.

\section{INTRODUCTION}

Alpha-L-arabinofuranosidase (EC 3.2.1.55) are the enzymes catalyze the hydrolysis of terminal non reducing $\alpha-\mathrm{L}-1, \quad 2-, \quad \alpha-\mathrm{L}-1,3-\quad$ L-arabinofuranosidic bonds in hemicelluloses such as arabinoxylan, L-arabinan and other L-arabinose-containing polysaccharides. The $\alpha$-L-arabinofuranosidase acts synergistically with other hemicellulases and pectic enzymes for complete degradation of hemicelluloses and pectin [1]. Its synergistic action with

Manuscript received February 15, 2013; revised May 21, 2013. This work was supported in part by the research grant of Hibah Tim Pascasarjana 2012, The Ministry of Education and Culture, Republic of Indonesia.

N. N. T. Puspaningsih is with the Department of Chemistry and Laboratory of Proteomic, Institute of Tropical Disease, Universitas Airlangga, Surabaya, 60115, Indonesia (phone: +62-31- 5922427, e-mail: nyomantri@yahoo.com).

Ratna Melinda, Handoko Darmokoesoemo, and Purkan are with Departement of Chemistry, Universitas Airlangga, 60115, Surabaya, Indonesia. other lignocelluloses degrading enzymes are promising tool in agro-industrial processes including improvement of animal feedstock quality, production of bioethanol from lignocelluloses material, production of important medicinal compounds and pulp treatment [2]. Since pulping and bleaching are both performed at high temperature, the application in paper industry needs a thermophilic hemicelulases preferably those active above $\mathrm{pH} 7$ [3].

A xylanolytic gene cluster from a thermophilic bacterium Geobacillus thermoleovorans IT-08 that had been isolated from Gunung Pancar hotspring (Bogor, West Java, Indonesia) was successfully cloned into plasmid pTP510 in Escherichia coli DH5a. This gene cluster encodes exo-xylanase (geneBank accession number DQ387047), $\beta$-xylosidase (DQ345777) and $\alpha$-L-arabinofuranosidase (DQ387046) [4]. In order to increase the activity of AbfA on basic condition, $a b f a$ gene had subjected to direct evolution using PCR-errorprone method, followed by cloning to M5 plasmid (excretory expression system)[5] and transformation to $E$. coli BL21(DE3). Screening of the extracellular AbfA, had showed some variants with increasing activity on $\mathrm{pH} 9$, one of which is variant A9 [6]. Nucleotide sequencing and alignment of $a b f a$ variant A9 to its wildtype (DQ 387046.1) showed three point mutations: A137G, A853G and T615A. In silico translation of the gene showed three amino acids substitution: Gln46Arg; Asp205Glu; Lys285Glu.

Amino acid substitution might affect the fold or function of the protein by disrupting the interacting forces within the protein as well as between protein and its environment. Studies on the effects of mutations have mostly been performed experimentally e.g. biochemical characterization of the mutations, which able to provides some insight into how the mutation affects activity; however, without structural information it is rare that the exact mechanism responsible for a change in activity can be characterized. Due to difficulties in experimental determination of protein structure, a bioinformatics approach is very useful in predicting the protein structure [7]. An understanding of correlation between mutation and protein function and stability is important for designing, engineering or developing a new enzyme [8]. This study aims to determine the biochemical properties of the AbfA variant (Q46R; D205E; K285E) as well as identify the correlation between biochemical property changes and modification on its tertiary structure, using protein tertiary structure model.

\section{MAterials AND MEthodS}

\section{A. Microorganism and Media Culture}


E. coli BL21(DE3)/ pBM5abf variant (A137G, A853G and T615A) was grown in sterile Luria-Bertani (LB) medium supplemented with $100 \mu \mathrm{g} / \mathrm{ml}$ Ampicillin, $2.5 \mathrm{mM}$ IPTG and $10 \mathrm{mM}$ Glycine. Sterile LB medium and Glycine were prepared by autoclaving the medium for $15 \mathrm{~min}$ at $121^{\circ} \mathrm{C}$ while the sterile IPTG was prepared by filtering the IPTG solution using $0.22 \mu \mathrm{m}$ filter.

\section{B. Production of AbfA Variant}

AbfA variant was produced using the method described on [6] with some modification. The cultures were grown in LB medium containing $100 \mu \mathrm{g} / \mathrm{ml}$ Ampicillin and incubated under shaking condition $(150 \mathrm{rpm})$ at $37^{\circ} \mathrm{C}$ until the optical density at $600 \mathrm{~nm}\left(\mathrm{OD}_{600}\right)$ measured by spectrophotometer (UV-1800, Shimadzu) was 0.5. Once the $\mathrm{OD}_{600}$ has reached 0.5 , sterile IPTG was added to the culture until final concentration $2.5 \mathrm{mM}$. The incubation continued under shaking condition $(150 \mathrm{rpm})$ at $30^{\circ} \mathrm{C}$ up to $24 \mathrm{~h}$. At the 4 th hour, sterile Glycine was added until final concentration 10 $\mathrm{mM}$. Culture were taken after $24 \mathrm{~h}$ incubation and centrifuged (3500rpm) for $10 \mathrm{~min}$. The cell pellet obtained was then resuspended in phosphate buffer ( $\mathrm{pH} 7)$. After that cell suspension was lysed by ultrasonicator (Soniprep 150 Sanyo) and centrifuged (12000rpm) for $10 \mathrm{~min}$ to produce crude enzymes.

\section{Partial Purification}

The crude enzyme was partially purified by heat treatment at $70^{\circ} \mathrm{C}$ in an hour. The denatured protein was separated with the undenatured one by centrifugation at $4^{\circ} \mathrm{C}$ (12000rpm, 15 min). The partially purified enzyme was used for the biochemical properties characterization including determination of optimum $\mathrm{pH}$ and temperature as well as $\mathrm{pH}$ stability and thermostability.

\section{Enzyme Activity Assay}

Enzyme activity was measured by incubating $20 \mu \mathrm{L}$ enzyme with $180 \mu \mathrm{L}$ pNPA $1 \mathrm{mM}$ in phosphate buffer $\mathrm{pH} 7$, at $70^{\circ} \mathrm{C}$ for 30 minutes. After 30 minutes incubation, $200 \mu \mathrm{L}$ $\mathrm{Na}_{2} \mathrm{CO}_{3} 0.5 \mathrm{M}$ was then added, followed by $600 \mu \mathrm{L}$ aquadest. The absorbance was measured at $405 \mathrm{~nm}$ using spectrophotometer. One unit of enzyme activity was defined as $\mu \mathrm{mol}$ p-nitrophenol liberated by $1 \mathrm{~mL}$ of enzyme per minute at incubation condition.

\section{E. Determination of Optimum $\mathrm{pH}$ and Temperature}

The optimum temperature of enzyme was determined by measuring the enzyme activity towards pNPA diluted in phosphate buffer $\mathrm{pH} 7$ at various temperatures $\left(50-90^{\circ} \mathrm{C}\right)$. The optimum $\mathrm{pH}$ of enzyme was determined by measuring the enzyme activity at various $\mathrm{pH}$ (6-10). Incubation of enzyme and substrate were held at $70^{\circ} \mathrm{C}$. The buffers used were: phosphate citrate buffer $(\mathrm{pH} \mathrm{6})$, phosphate buffer $(\mathrm{pH}$ 7-8), Glycine-NaOH buffer ( $\mathrm{pH} 9-10)$.

\section{F. Determination of $\mathrm{pH}$ Stability}

$\mathrm{pH}$ stability was assessed by diluting the enzyme at various $\mathrm{pH}$ and same concentration for each $\mathrm{pH}$ then stored at $4^{\circ} \mathrm{C}$ for $24 \mathrm{~h}$. On $0 \mathrm{~h}$ and $24 \mathrm{~h}$, the enzyme activity was measured at its optimum $\mathrm{pH}$ and temperature. Residual activity at $24 \mathrm{~h}$ is the comparison between activity at $24 \mathrm{~h}$ and activity at $0 \mathrm{~h}$.

\section{G. Determination of Temperature Stability}

Thermostability was assessed by incubating the enzyme at $70^{\circ} \mathrm{C}$ up to 24 hours. The activity of enzyme measured at 0 , $5^{\text {th }}, 9^{\text {th }}, 16^{\text {th }}$ and $24^{\text {th }}$ hour using same procedure as described in enzyme activity assay at optimum and $\mathrm{pH}$ temperature. Residual activity at $\mathrm{x}$ hour is the comparison between activity at $\mathrm{x}$ hour and activity at $\mathrm{Oh}$.

\section{H. Protein Tertiary Structure Modeling}

Protein tertiary structure was modeled using homology modeling method by Swiss Model [9] using $\alpha$-L-arabinofuranosidase from Geobacillus stearothermophilus T-6 as template [10].

\section{Determination of RMSD}

The RMSD changes was determined using Super Pose [11]

\section{J. Determination of Non Covalent Interaction and Solvent Accessibility Surface}

Solvent Accessibility Surface and non covalent interactions including Hydrogen bonds, Van der Waals Interactions were determined using Chimera 1.6.7. Electrostatic interaction were determined by measuring the distance between charged atom using Chimera 1.6.7 [12]

\section{$K$. Determination of $\Delta \Delta G$}

The changes in $\Delta \mathrm{G}$ upon mutation $(\Delta \Delta \mathrm{G})$ were determined using PoP MuSiC-2.0 [13].

\section{RESULTS AND DISCUSSION}

\section{A. Expression and Characterization of AbfA Variant}

Expression of intracellular AbfA variant (Q46R; D205E; K285E) was detected by using SDS PAGE. A $61 \mathrm{KDa}$ band was present, corresponded to intracellular AbfA variant (data not shown). The molecular weight of AbfA produced by $G$. thermoleovorans IT-08 is $58 \mathrm{kDa}$ but since $a b f a$ variant gene was on M5 plasmid system [5], the intracellular protein synthesized would still have the signal peptide, gave an addition to the molecular weight [14], [15]. The band showed at polyacrylamide gel $(61 \mathrm{KDa})$ was in agreement with the theoretical molecular weight of protein plus signal peptide estimated by ProtParam [16]. Partial purification by heat treatment at $70^{\circ} \mathrm{C}$ was based on thermophilic property of AbfA [4]. The heat treatment would denature most mesophilic proteins produced by $E$. coli but not the termophilic AbfA protein, resulted in increase of purity by 17.60 fold (Table I).

AbfA variant displayed an optimum activity at $\mathrm{pH} 7$ (Fig. 1) and $70^{\circ} \mathrm{C}$ (Fig. 2). AbfA variant showed no differences in optimum temperature with extracellular AbfA synthesized by E. coli BL21(DE3)/pBM5abf. The optimum $\mathrm{pH}$ of AbfA variant was relatively same as the extracellular AbfA synthesized by $E$. coli BL21(DE3)/ pBM5abf, which is between the range of neutral to slightly basic ( $\mathrm{pH} 7-8)$ [6].

Mutation on abfa gene did not affect the optimum condition for catalysis since the substituted amino acids were not located at or around the active site [17]-[19], as shown on Fig. 3. Residues involved in catalysis are Glu29, Arg69, Asn74, Asn174, Glu175, His244, Tyr246, Glu294, and 
Gln351 [10].

TABLE I: ABFA VARIANT PURIFICATION TABLE

\begin{tabular}{|c|c|c|c|c|c|c|c|c|}
\hline SAMPLE & $\begin{array}{c}{[\mathrm{PNP}]} \\
(\mu \mathrm{G} / \mathrm{ML})\end{array}$ & $\begin{array}{c}\text { [PROTEIN] } \\
(\mu \mathrm{G} / \mathrm{ML})\end{array}$ & $\begin{array}{c}\text { ACTIVITY } \\
(\mathrm{U} / \mathrm{ML})\end{array}$ & $\begin{array}{c}\text { VOLUME } \\
(\mathrm{ML})\end{array}$ & $\begin{array}{c}\text { TOTAL } \\
\text { ACTIVITY }\end{array}$ & $\begin{array}{c}\text { SPECIFIC ACTIVITY } \\
(\mathrm{U} / \mathrm{ML} . \mathrm{MG})\end{array}$ & $\begin{array}{c}\text { YIELD } \\
\text { PURIFICATION } \\
\text { FOLD }\end{array}$ \\
\hline CRUDE & 0.154 & 32968.42 & 0.36868 & 5 & 1.8434 & 0.011183 & $100 \%$ & 1 \\
\hline $\begin{array}{c}\text { PARTIALLY } \\
\text { PURIFIED }\end{array}$ & 0.110 & 1336.67 & 0.26303 & 3.5 & 0.92060 & 0.1967812 & $50 \%$ & 17.60 \\
\hline
\end{tabular}

TABLE II: SUMMARY OF INTERMOLECULAR HYDROGEN BONDS, VAN DER WAALS INTERACTION AND ELECTROSTATIC INTERACTION FORMED BY RESIDUE 46, 205 , AND 285

\begin{tabular}{|c|c|c|c|c|c|c|}
\hline \multirow{2}{*}{ Interaction } & \multicolumn{7}{|c|}{ Residue number: } \\
\cline { 2 - 8 } & Gln46 & Arg46 & Asp205 & Glu205 & Gln285 & Glu285 \\
\hline Hydrogen bond & 1 & 1 & 5 & 2 & 0 & 0 \\
\hline Van der Waals & 24 & 21 & 33 & 32 & 2 & 1 \\
\hline Electrostatic & 0 & 0 & 0 & 1 & 0 & 1 (weak) \\
\hline
\end{tabular}

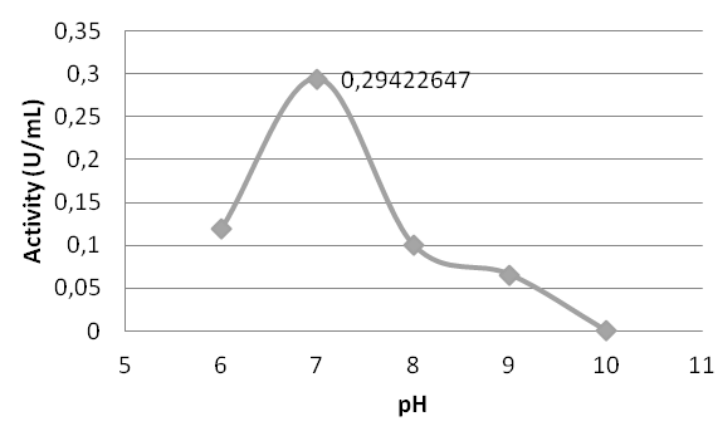

Fig. 1. The activity of AbfA variant on various $\mathrm{pH}$.

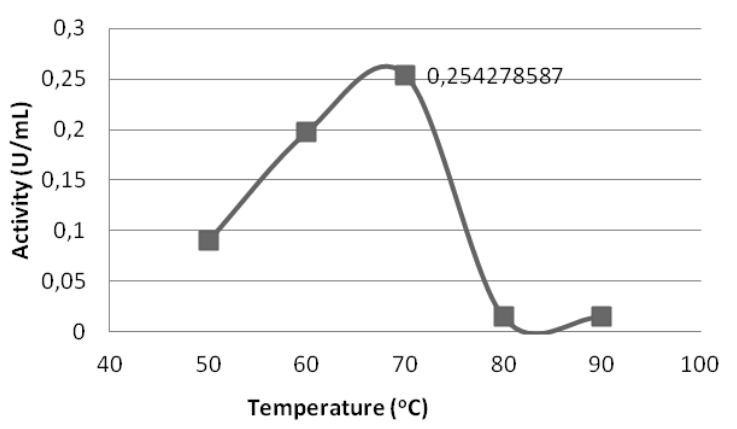

Fig. 2. The activity of AbfA variant on various incubation temperatures.

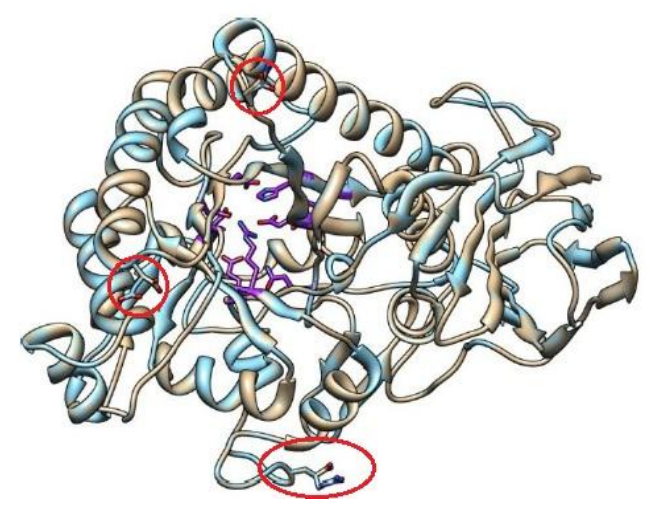

Fig. 3. Superimpose of AbfA wildtype (brown) and variant (blue). Substituted amino acids were showed inside red circle while the amino acids involved in catalysis were purple colored.

AbfA variant lost $25 \%$ of its activity at $70^{\circ} \mathrm{C}$ after $9 \mathrm{~h}$ and retained only $34 \%$ of its activity over $16 \mathrm{~h}$. Meanwhile, AbfA wildtype still showed $95 \%$ activity after $9 \mathrm{~h}$ and retained $73 \%$ of its activity over $16 \mathrm{~h}$ (Fig. 4). The $\mathrm{pH}$ stability assessment showed that both AbfA variant and wildtype maintained more than $86 \%$ of activity on incubation at $\mathrm{pH} 6-9$ over $24 \mathrm{~h}$ thus assumed as stable at pH 6-9 (Fig. 5).

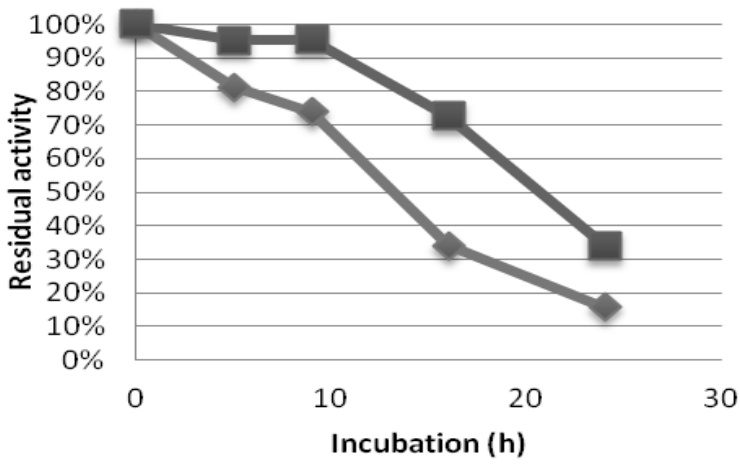

Fig. 4. Effect of temperature at $70^{\circ} \mathrm{C}$ on the stability of Abf A wildtype (-) and variant $(\bullet)$.

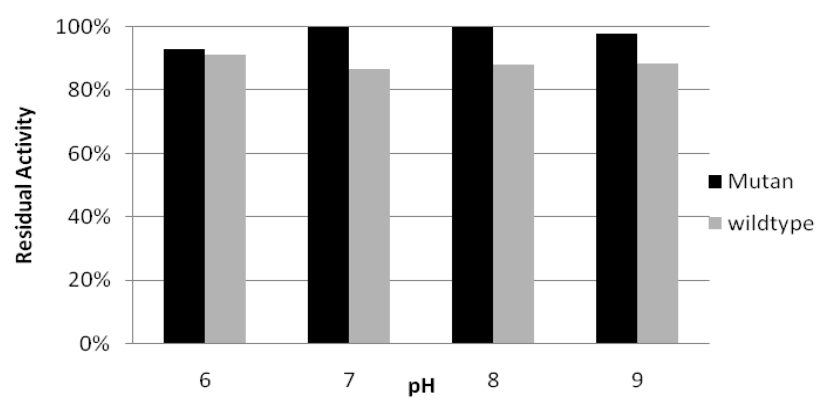

Fig. 5. Effect of $\mathrm{pH}$ 6-9 on the stability of AbfA wildtype and variant.

\section{B. In Silico Study of AbfA Variant}

AbfA from Geobacillus thermoleovorans IT-08 was found to be $96 \%$ identical to $\alpha$-L-arabinofuranosidase from Geobacillus stearothermophilus T-6 thus it was used as template for construction of homology model of AbfA variant and wildtype. Superimpose of AbfA variant to its wildtype showed total RMSD 0.05 (Fig. 3). The amino acids replacement due to gene mutation resulted in several changes in Hydrogen bonds, Van der Waals interaction and electrostatic interaction, as summarized on Table II. Solvent accessibility area of AbfA variant and wildtype were 19000.7 and 19011.8, respectively. Solvent accessible surface area is one of the parameters characterizing the compactness of protein [20]-[21]. The hypothesis in protein flexibility stated that rigidity is a prequisite for high protein thermostability, supported by some studies conclude that hyperthermophilic 
proteins are more rigid enzymes [3]. Increase in solvent accessible surface area of AbfA mutant showed a less compact protein structure, affecting the thermostability of AbfA variant.

The amino acids replacement due to gene mutation resulted in several changes in Hydrogen bonds, Van der Waals interaction and electrostatic interaction, as summarized on Table II. Complete list of the non covalent bonds is provided on supplementary data.

Substitutions of Gln46Arg is not affecting the polarity but the charge [22], gave a chance to the residue to make an electrostatic interaction. However, the amino acid changes did not make any change in electrostatic interaction because the three negatively charged residues around Arg46 (Asp48, Asp55, Glu58) were at $6.5-11 \AA$ in distance to Arg46 while the maximum distance for salt bridge formation is $4 \AA$ [23], [24]. The only Hydrogen bond formed, was between atoms at protein backbone so it was not affected by the mutation (Fig. $6)$.
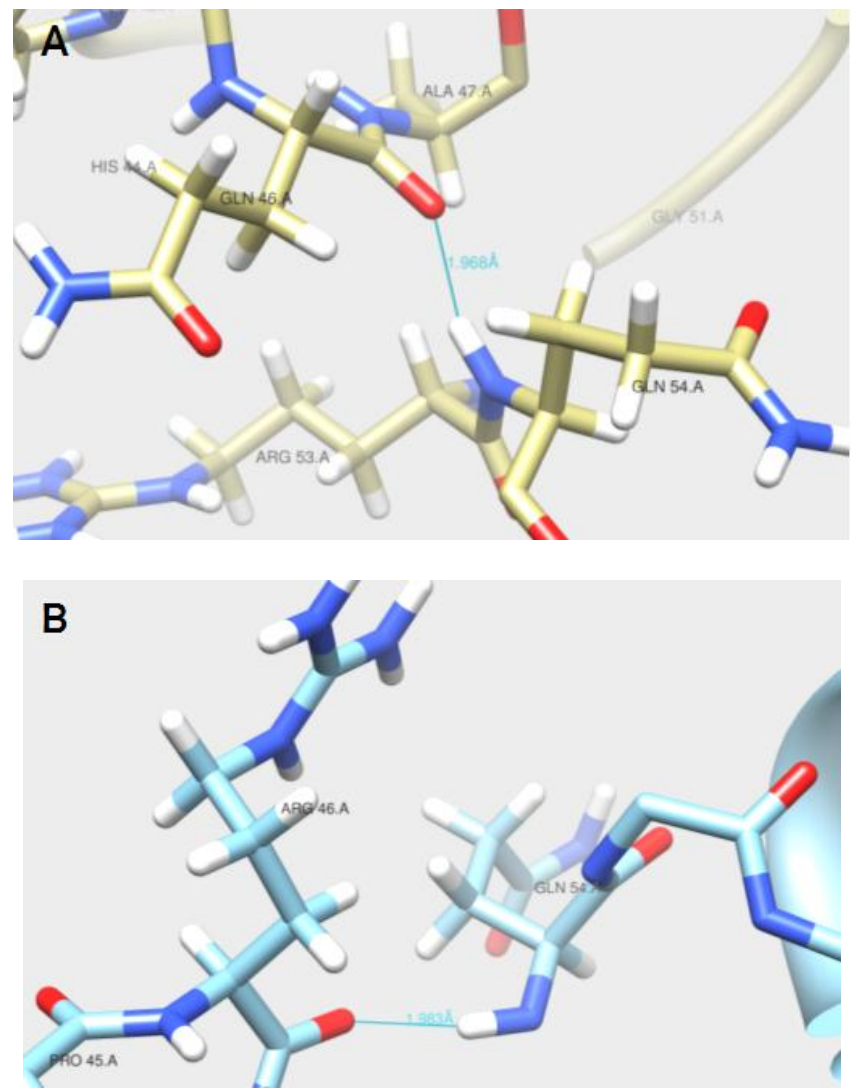

Fig. 6. Hydrogen bond (blue line) formed by residue 46 (A: before mutation; B: after mutation).

The only change at this position was reduction of 3 Van der Waals interactions (see supplementary data). Prediction of mutant stability using $\Delta \Delta \mathrm{G}$ showed the $\Delta \Delta \mathrm{G}$ was +0.22 .

It means that mutation in this position directing to destabilization, most probably caused by reduction of Van der Waals interaction.

Theoretically, the Asp205Glu substitution might not have a huge effect since those two has similar side chain, differ only by a methylene group [22]. However, the in silico study showed reduction of 3 hydrogen bonds (Fig. 7) and 1 Van der Waals interaction (picture not shown), also addition of 1 electrostatic interaction (His146-Glu205) due to the replacement (Fig. 8). A repulsive force arose from free electron pair at His146 N and Glu205 O, compensating the attractive force formed by electrostatic interaction. Replacement at this position showed a destabilization with $\Delta \Delta \mathrm{G}+2.32$. The destabilization was mainly because of the reduction of 3 Hydrogen bonds.
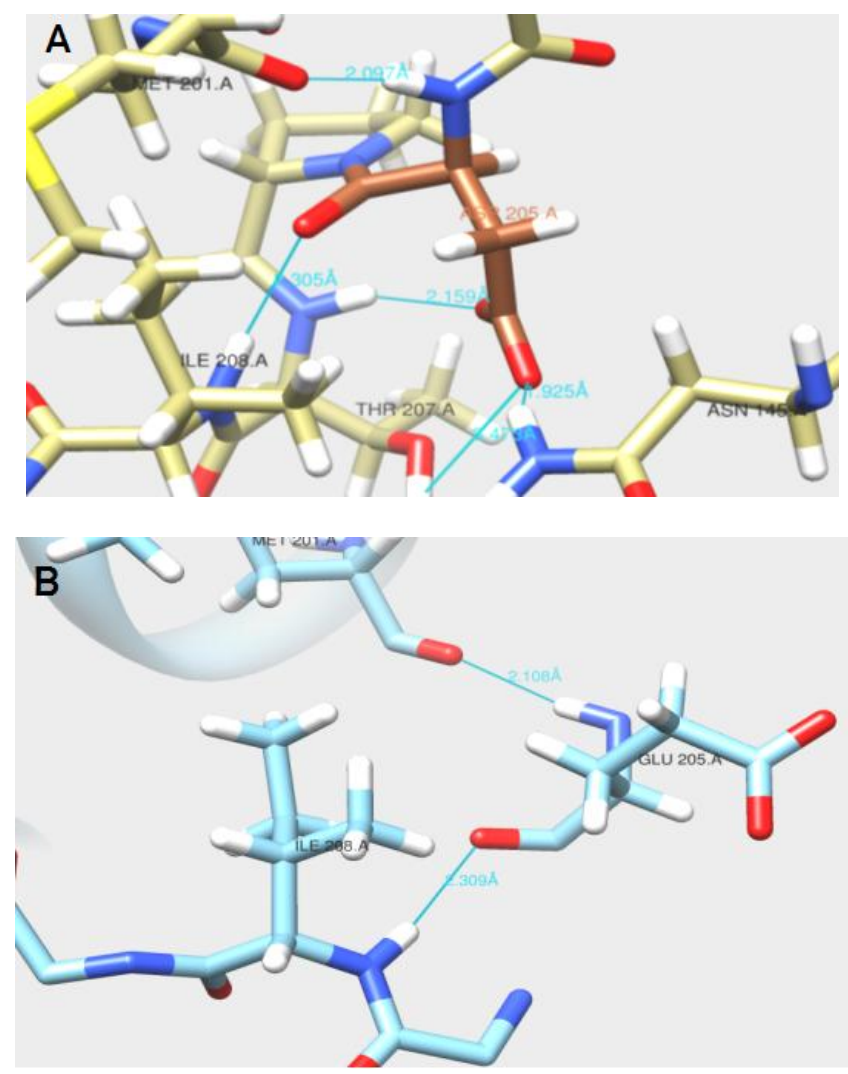

Fig. 7. Hydrogen bonds (blue line) formed by Asp205 (A) and Glu205 (B)

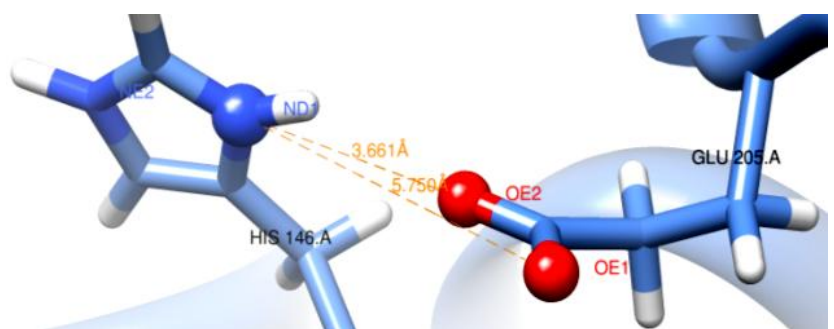

Fig. 8. Salt bridge between Glu205 OE2 and His146 ND1 (3.661 $)$.

Lys285Glu changes caused a side chain charge inversion, from positively to negatively charged [22]. The replacement at this position actually was more favorable since most charged amino acids around position 285 are positively charged: Lys279, Lys281, Lys282, Arg283 and Lys286. The charge inversion reduced the repulsive force arose from same charges around residue 285. Although amino acid at this position was charged, they were not involved in any salt bridge because of spatial hindrance. The closest negative amino acid to Lys285 was Asp276, whose charged atom was

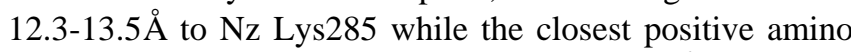
acid to Glu285 was Lys279, whose NZ was $4.6 \AA$ to Glu285 OE1. It was assumed that Glu285 OE1 create a weak electrostatic interaction with Lys $279 \mathrm{NZ}$ because the charged atom distance was longer than salt bridge's maximum distance. The other change following replacement at this position was reduction of 1 Van der Waals interaction. This 
residue (either before or after mutation) did not form any Hydrogen bond. The facing-out side chain packing cause the atoms of residue 285 were at unfavourable distance to form interaction (Fig. 9). Despite Glu285 formed less Van der Waals interaction than Lys285 did, but the weak electrostatic interaction formed and the charge inversion were able to compensate the destabilization caused by reduction of a Van der Waals interactions. The $\Delta \Delta \mathrm{G}$ value of amino acid substitution on residue 285 was -0.09 .

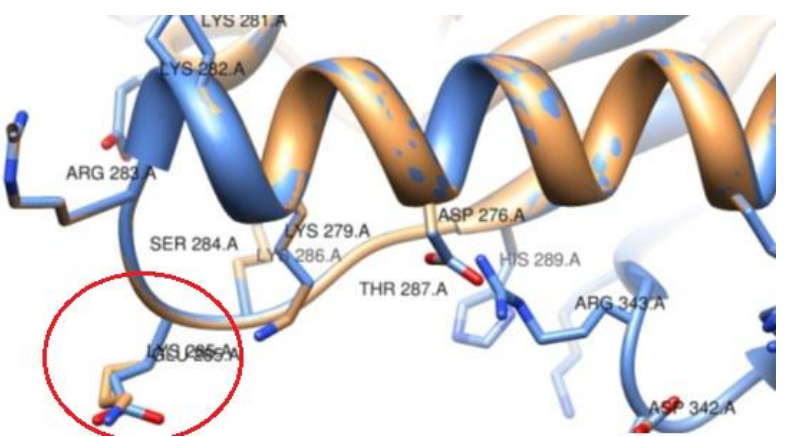

Fig. 9. Side chain packing of residue 285( before mutation: orange; after mutation: blue colored)

Qualitatively, there were reductions in non covalent interaction due to amino acid replacement, causing $\Delta$ Hfolding of AbfA variant smaller than its wildtype. The maximum approximate bond energy for Hydrogen bond, Van der Waals interaction and electrostatic interaction are 10, 5, and $20 \mathrm{~kJ} / \mathrm{mol}$, respectively [22]. Reduction of 3 hydrogen bonds and 5 Van der Waals interaction also formation of 2 electrostatic interactions prior to amino acids substitution would reduce $15 \mathrm{~kJ} / \mathrm{mol}$ in bond energy. According to the equation $\Delta \mathrm{G}=\Delta \mathrm{H}-\mathrm{T} . \Delta \mathrm{S}$ [22], a small $\Delta \mathrm{H}$ (less heat released) causing a small $\Delta \mathrm{G}$ value. The $\Delta \mathrm{G}_{\text {folding }}$ depict amount of energy released to convert unfolding to folding state. Hence, the smaller $\Delta \mathrm{H}_{\text {folding }}$ value, the smaller $\Delta \mathrm{G}_{\text {folding. Small value }}$ of $\Delta \mathrm{G}_{\text {folding }}$ means unfolding is easier to occur. The smaller $\Delta \mathrm{H}_{\text {folding }}$ of $\mathrm{AbfA}$ variant cause Abf A variant was more susceptible to unfolding than AbfA wildtype when treated with same heating treatment or in other words, cause AbfA variant has less thermostability than AbfA wildtype.

\section{CONCLUSION}

The partially purified AbfA variant (Q46R, D205E, $\mathrm{K} 285 \mathrm{E}$ ) displayed optimum activity at $\mathrm{pH} 7$ and $70^{\circ} \mathrm{C}$, was stable for 24 hours at $\mathrm{pH} 6-9$ (at $4^{\circ} \mathrm{C}$ ) and lost almost $70 \%$ of its activity on 16 hours incubation at $70^{\circ} \mathrm{C}$. The decrease in thermostability was prior to reduction in non covalent interaction driven by changes in structure.

\section{APPENDIX}

\section{A. Supplementary 1. Hydrogen Bonds on AbfA}

1) On residue 46

\begin{tabular}{|c|c|c|c|c|c|}
\hline $\begin{array}{c}\text { Donor } \\
(\mathrm{D})\end{array}$ & $\begin{array}{c}\text { Acceptor } \\
(\mathrm{A})\end{array}$ & Hydrogen & $\begin{array}{c}\text { Distance } \\
\text { D..A }\end{array}$ & $\begin{array}{c}\text { Distance } \\
\text { D-H..A }\end{array}$ & notes \\
\hline Gln 54 N & Gln 46 N & Gln 54 H & 2.934 & 1.968 & $\begin{array}{c}\text { Before } \\
\text { mutation }\end{array}$ \\
\hline Gln 54 N & Arg 46 O & Gln 54 H & 2.946 & 1.983 & $\begin{array}{c}\text { After } \\
\text { mutation }\end{array}$ \\
\hline
\end{tabular}

2) On residue 205

\begin{tabular}{|c|c|c|c|c|c|}
\hline Donor (D) & $\begin{array}{l}\text { Acceptor } \\
\text { (A) }\end{array}$ & Hydrogen & $\begin{array}{c}\text { Distance } \\
\text { D...A }\end{array}$ & $\begin{array}{c}\text { Distance } \\
\text { D-H..A }\end{array}$ & notes \\
\hline Asn 145 ND2 & Asp 205 OD2 & Asn $145 \mathrm{HD} 2$ & 2.835 & 1.925 & \multirow{5}{*}{$\begin{array}{l}\text { Before } \\
\text { mutation }\end{array}$} \\
\hline Asp $205 \mathrm{~N}$ & Met $201 \mathrm{O}$ & Asp $205 \mathrm{H}$ & 3.049 & 2.097 & \\
\hline Thr $207 \mathrm{~N}$ & Asp 205 OD1 & Thr $207 \mathrm{H}$ & 3.111 & 2.159 & \\
\hline Ile $208 \mathrm{~N}$ & Asp $205 \mathrm{O}$ & ILE $208 \mathrm{H}$ & 3.298 & 2.305 & \\
\hline Thr 207 OG & Asp $205 \mathrm{~N}$ & Thr 207 HG & 3.440 & 2.473 & \\
\hline Glu 205 N & Met $201 \mathrm{O}$ & Glu $205 \mathrm{H}$ & 3.062 & 2.108 & \multirow[t]{2}{*}{ After mutation } \\
\hline Ile $208 \mathrm{~N}$ & Glu 205 O & Ile $208 \mathrm{H}$ & 3.303 & 2.309 & \\
\hline
\end{tabular}

3) On residue 285

No Hydrogen bond found.

B. Supplementary 2. Van der Waals Interaction on AbfA VDW overlap $>=-0,4$ angstroms.

1) $G \ln 46$

\begin{tabular}{|c|cc|cc|c|c|}
\hline No. & atom1 & & atom2 & & overlap & distance \\
\hline 1 & GLN 46 & H & HIS 44 & HD2 & 0.818 & 1.182 \\
\hline 2 & GLN 46 & H & HIS 44 & CD2 & 0.614 & 2.086 \\
\hline 3 & GLN 46 & N & HIS 44 & HD2 & 0.571 & 2.054 \\
\hline 4 & GLN 46 & O & GLN 54 & H & 0.512 & 1.968 \\
\hline 5 & GLN 46 & N & HIS 44 & CD2 & 0.272 & 3.053 \\
\hline 6 & GLN 46 & O & GLN 54 & N & 0.171 & 2.934 \\
\hline 7 & GLN 46 & OE1 & ASP 55 & HB3 & 0.142 & 2.338 \\
\hline 8 & GLN 46 & CA & HIS 44 & HD2 & 0.027 & 2.673 \\
\hline
\end{tabular}

\begin{tabular}{|c|cc|cc|c|c|}
9 & GLN 46 & O & GLN 54 & CB & -0.010 & 3.190 \\
\hline 10 & GLN 46 & CB & HIS 44 & HD2 & -0.024 & 2.724 \\
\hline 11 & GLN 46 & HB3 & HIS 44 & CD2 & -0.024 & 2.724 \\
\hline 12 & GLN 46 & H & HIS 44 & C & -0.027 & 2.727 \\
\hline 13 & GLN 46 & N & HIS 44 & O & -0.047 & 3.152 \\
\hline 14 & GLN 46 & HB3 & HIS 44 & HD2 & -0.092 & 2.092 \\
\hline 15 & GLN 46 & CB & HIS 44 & CD2 & -0.146 & 3.546 \\
\hline 16 & GLN 46 & O & GLN 54 & HB3 & -0.196 & 2.676 \\
\hline 17 & GLN 46 & OE1 & ASP 55 & CB & -0.208 & 3.388 \\
\hline 18 & GLN 46 & H & HIS 44 & CG & -0.299 & 2.999 \\
\hline 19 & GLN 46 & NE2 & HIS 44 & HE2 & -0.301 & 2.926 \\
\hline 20 & GLN 46 & C & GLN 54 & H & -0.302 & 3.002 \\
\hline 21 & GLN 46 & CA & HIS 44 & CD2 & -0.328 & 3.728 \\
\hline
\end{tabular}




\begin{tabular}{|c|cc|cc|c|c|}
22 & GLN 46 & HB3 & HIS 44 & NE2 & -0.368 & 2.993 \\
\hline 23 & GLN 46 & H & HIS 44 & NE2 & -0.381 & 3.006 \\
\hline 24 & GLN 46 & H & PRO 45 & CD & -0.396 & 3.096 \\
\hline
\end{tabular}

2) $\operatorname{Arg} 46$

\begin{tabular}{|c|ccc|cc|c|c|}
\hline No. & \multicolumn{3}{|c|}{ atom1 } & \multicolumn{2}{|c|}{ atom2 } & overlap & distance \\
\hline 1 & ARG & 46 & H & HIS 44 & HD2 & 0.823 & 1.177 \\
\hline 2 & ARG & 46 & H & HIS 44 & CD2 & 0.620 & 2.080 \\
\hline 3 & ARG & 46 & N & HIS 44 & HD2 & 0.581 & 2.044 \\
\hline 4 & ARG & 46 & O & GLN 54 & H & 0.497 & 1.983 \\
\hline 5 & ARG & 46 & N & HIS 44 & CD2 & 0.280 & 3.045 \\
\hline 6 & ARG & 46 & O & GLN 54 & N & 0.159 & 2.946 \\
\hline 7 & ARG & 46 & HB2 & HIS 44 & CD2 & 0.085 & 2.615 \\
\hline 8 & ARG & 46 & CA & HIS 44 & HD2 & 0.048 & 2.652 \\
\hline 9 & ARG & 46 & CB & HIS 44 & HD2 & 0.021 & 2.679 \\
\hline 10 & ARG & 46 & HB2 & HIS 44 & HD2 & 0.002 & 1.998 \\
\hline 11 & ARG & 46 & O & GLN 54 & CB & -0.009 & 3.189 \\
\hline 12 & ARG & 46 & H & HIS 44 & C & -0.036 & 2.736 \\
\hline 13 & ARG & 46 & N & HIS 44 & O & -0.060 & 3.165 \\
\hline 14 & ARG & 46 & CB & HIS 44 & CD2 & -0.090 & 3.490 \\
\hline 15 & ARG & 46 & O & GLN 54 & HB2 & -0.191 & 2.671 \\
\hline 16 & ARG & 46 & HB2 & HIS 44 & NE2 & -0.262 & 2.887 \\
\hline 17 & ARG & 46 & H & HIS 44 & CG & -0.299 & 2.999 \\
\hline 18 & ARG & 46 & C & GLN 54 & H & -0.302 & 3.002 \\
\hline 19 & ARG & 46 & CA & HIS 44 & CD2 & -0.306 & 3.706 \\
\hline 20 & ARG & 46 & H & HIS 44 & NE2 & -0.370 & 2.995 \\
\hline 21 & ARG & 46 & H & PRO 45 & CD & -0.388 & 3.088 \\
\hline
\end{tabular}

3) Lys 285

\begin{tabular}{|c|cc|cc|c|c|}
\hline & atom & \multicolumn{2}{|c|}{ atom } & & \\
No. & 1 & & 2 & overlap & distance \\
\hline 1 & LYS 285 & C & LYS 279 & HE3 & -0.362 & 3.062 \\
\hline 2 & LYS 285 & H & LYS 286 & H & -0.383 & 2.383 \\
\hline
\end{tabular}

4) Glu 285

\begin{tabular}{|c|cc|cc|c|c|}
\hline No & atom & \multicolumn{2}{|c|}{ atom } & & \\
$\cdot$ & 1 & 2 & overlap & distance \\
\hline & & & HE & & \\
1 & GLU 285 & C & LYS 279 & 3 & -0.387 & 3.087 \\
\hline
\end{tabular}

5) Asp205

\begin{tabular}{|c|cc|ccc|c|c|}
\hline No. & \multicolumn{2}{|c|}{ atom1 } & \multicolumn{2}{|c|}{ atom2 } & overlap & distance \\
\hline 1 & ASP 205 & OD2 & ASN 145 & HD21 & 0.555 & 1.925 \\
\hline 2 & ASP 205 & H & MET 201 & O & 0.383 & 2.097 \\
\hline 3 & ASP 205 & OD1 & THR 207 & OG1 & 0.327 & 2.653 \\
\hline 4 & ASP 205 & OD1 & THR 207 & H & 0.321 & 2.159 \\
\hline 5 & ASP 205 & O & ILE 208 & HG12 & 0.308 & 2.172 \\
\hline 6 & ASP 205 & OD2 & ASN 145 & ND2 & 0.270 & 2.835 \\
\hline 7 & ASP 205 & C & THR 207 & H & 0.190 & 2.510 \\
\hline 8 & ASP 205 & O & ILE 208 & H & 0.175 & 2.305 \\
\hline 9 & ASP 205 & HA & PRO 206 & HD2 & 0.096 & 1.904 \\
\hline
\end{tabular}

\begin{tabular}{|c|cc|cc|c|c|}
10 & ASP 205 & C & LYS 202 & O & 0.070 & 3.110 \\
\hline 11 & ASP 205 & N & MET 201 & O & 0.056 & 3.049 \\
\hline 12 & ASP 205 & O & THR 207 & N & 0.020 & 3.085 \\
\hline 13 & ASP 205 & O & ILE 208 & CG1 & 0.002 & 3.178 \\
\hline 14 & ASP 205 & OD1 & THR 207 & N & -0.006 & 3.111 \\
\hline 15 & ASP 205 & CG & THR 207 & OG1 & -0.011 & 3.211 \\
\hline 16 & ASP 205 & O & ILE 208 & HG22 & -0.099 & 2.579 \\
\hline 17 & ASP 205 & CG & ILE 208 & HG22 & -0.141 & 2.841 \\
\hline 18 & ASP 205 & OD1 & PRO 206 & N & -0.187 & 3.292 \\
\hline 19 & ASP 205 & O & ILE 208 & N & -0.193 & 3.298 \\
\hline 20 & ASP 205 & OD2 & ASN 145 & HB3 & -0.195 & 2.675 \\
\hline 21 & ASP 205 & O & ILE 208 & CG2 & -0.234 & 3.414 \\
\hline 22 & ASP 205 & CG & ASN 145 & HD21 & -0.238 & 2.938 \\
\hline 23 & ASP 205 & OD2 & THR 207 & OG1 & -0.253 & 3.233 \\
\hline 24 & ASP 205 & OD1 & THR 207 & CB & -0.256 & 3.436 \\
\hline 25 & ASP 205 & N & LYS 202 & O & -0.262 & 3.367 \\
\hline 26 & ASP 205 & O & THR 207 & H & -0.263 & 2.743 \\
\hline 27 & ASP 205 & O & LYS 202 & HA & -0.271 & 2.751 \\
\hline 28 & ASP 205 & OD2 & ASN 145 & CB & -0.293 & 3.473 \\
\hline 29 & ASP 205 & H & LYS 202 & C & -0.319 & 3.019 \\
\hline 30 & ASP 205 & OD1 & THR 207 & CG2 & -0.372 & 3.552 \\
\hline 31 & ASP 205 & CG & ILE 208 & CG2 & -0.378 & 3.778 \\
\hline 32 & ASP 205 & OD2 & ILE 208 & CG2 & -0.383 & 3.563 \\
\hline 33 & ASP 205 & OD2 & ILE 208 & HG22 & -0.396 & 2.876 \\
\hline
\end{tabular}

\section{6) Glu205}

\begin{tabular}{|c|cc|cc|c|c|}
\hline No. & \multicolumn{2}{|c|}{ atom1 } & \multicolumn{2}{|c|}{ atom2 } & overlap & distance \\
\hline 1 & GLU 205 & HG3 & VAL 204 & HG11 & 0.404 & 1.596 \\
\hline 2 & GLU 205 & H & MET 201 & O & 0.372 & 2.108 \\
\hline 3 & GLU 205 & HG2 & ASN 145 & CB & 0.316 & 2.384 \\
\hline 4 & GLU 205 & O & ILE 208 & HG13 & 0.303 & 2.177 \\
\hline 5 & GLU 205 & C & THR 207 & H & 0.216 & 2.484 \\
\hline 6 & GLU 205 & CD & VAL 204 & O & 0.175 & 3.005 \\
\hline 7 & GLU 205 & O & ILE 208 & H & 0.171 & 2.309 \\
\hline 8 & GLU 205 & OE2 & VAL 204 & O & 0.143 & 2.817 \\
\hline 9 & GLU 205 & HG3 & VAL 204 & C & 0.127 & 2.573 \\
\hline 10 & GLU 205 & HG2 & ASN 145 & HB2 & 0.113 & 1.887 \\
\hline 11 & GLU 205 & HA & PRO 206 & HD3 & 0.074 & 1.926 \\
\hline 12 & GLU 205 & CG & VAL 204 & O & 0.070 & 3.110 \\
\hline 13 & GLU 205 & C & LYS 202 & O & 0.043 & 3.137 \\
\hline 14 & GLU 205 & N & MET 201 & O & 0.043 & 3.062 \\
\hline 15 & GLU 205 & HG3 & VAL 204 & CG1 & 0.030 & 2.670 \\
\hline 16 & GLU 205 & CG & VAL 204 & HG11 & 0.025 & 2.675 \\
\hline 17 & GLU 205 & O & THR 207 & N & 0.019 & 3.086 \\
\hline 18 & GLU 205 & O & ILE 208 & CG1 & 0.000 & 3.180 \\
\hline 19 & GLU 205 & HG2 & ASN 145 & HB3 & -0.054 & 2.054 \\
\hline 20 & GLU 205 & CG & ASN 145 & CB & -0.059 & 3.459 \\
\hline 21 & GLU 205 & HG3 & VAL 204 & O & -0.092 & 2.572 \\
\hline 22 & GLU 205 & O & ILE 208 & HG22 & -0.114 & 2.594 \\
\hline 23 & GLU 205 & CG & ASN 145 & HB2 & -0.176 & 2.876 \\
\hline & & & & & & \\
\hline
\end{tabular}




\begin{tabular}{|c|cc|cc|c|c|}
24 & GLU 205 & O & ILE 208 & N & -0.198 & 3.303 \\
\hline 25 & GLU 205 & O & ILE 208 & CG2 & -0.247 & 3.427 \\
\hline 26 & GLU 205 & CD & VAL 204 & C & -0.253 & 3.653 \\
\hline 27 & GLU 205 & O & LYS 202 & HA & -0.257 & 2.737 \\
\hline 28 & GLU 205 & N & LYS 202 & O & -0.266 & 3.371 \\
\hline 29 & GLU 205 & O & THR 207 & H & -0.268 & 2.748 \\
\hline 30 & GLU 205 & H & LYS 202 & C & -0.327 & 3.027 \\
\hline 31 & GLU 205 & CG & VAL 204 & CG1 & -0.353 & 3.753 \\
\hline 32 & GLU 205 & CG & ASN 145 & HB3 & -0.353 & 3.053 \\
\hline
\end{tabular}

\section{Supplementary 3: Distances between Charged Atoms on Residue 46, 205 Dan 285}

Electrostatic interaction on both AbfA wildtype and variant were determined by measured the distances between charged atoms located around charged mutated residue.

1) AbfA wildtype

\begin{tabular}{|c|ccc|ccc|c|}
\hline No. & \multicolumn{3}{|c|}{ Atom 1 } & \multicolumn{3}{c|}{ Atom 2 } & Distance $(\AA)$ \\
\hline 1 & Asp & 205 & OD1 & Lys & 166 & NZ & 7.418 \\
\hline 2 & Asp & 205 & OD2 & Lys & 166 & NZ & 6.664 \\
\hline 3 & Asp & 205 & OD1 & His & 146 & ND1 & 8.015 \\
\hline 4 & Asp & 205 & OD2 & His & 165 & ND1 & 11.480 \\
\hline 5 & Asp & 205 & OD1 & His & 165 & ND1 & 13.640 \\
\hline 6 & Asp & 205 & OD2 & Lys & 168 & NZ & 7.995 \\
\hline 7 & Asp & 205 & OD1 & Lys & 168 & NZ & 7.649 \\
\hline 8 & Lys & 285 & NZ & Asp & 276 & OD2 & 13.550 \\
\hline 9 & Lys & 285 & NZ & Asp & 276 & OD1 & 12.328 \\
\hline
\end{tabular}

\section{2) AbfA variant (Gln46Arg; Asp205Glu; Lys285Glu)}

\begin{tabular}{|c|c|c|c|c|c|c|c|}
\hline No. & \multicolumn{3}{|c|}{ Atom 1} & \multicolumn{3}{|c|}{ Atom 2} & $\begin{array}{c}\text { Distance } \\
(\AA)\end{array}$ \\
\hline 1 & Glu & 285 & $\mathrm{OE} 2$ & Arg & 283 & NH1 & 11.898 \\
\hline 2 & Glu & 285 & OE2 & Arg & 283 & $\mathrm{NH} 2$ & 12.989 \\
\hline 3 & Glu & 285 & OE2 & Lys & 279 & $\mathrm{NZ}$ & 6.505 \\
\hline 5 & Glu & 285 & OE1 & His & 289 & NE2 & 12.188 \\
\hline 6 & Glu & 285 & OE1 & Lys & 279 & $\mathrm{NZ}$ & 4.796 \\
\hline 8 & Glu & 285 & $\mathrm{OE} 2$ & Lys & 282 & $\mathrm{NZ}$ & 15.598 \\
\hline 9 & Glu & 285 & OE2 & Lys & 286 & $\mathrm{NZ}$ & 12.907 \\
\hline 10 & Arg & 46 & $\mathrm{NH} 2$ & Asp & 55 & OD2 & 6.568 \\
\hline 11 & Arg & 46 & $\mathrm{NH} 2$ & Asp & 55 & OD2 & 5.980 \\
\hline 12 & Arg & 46 & $\mathrm{NH} 1$ & Asp & 55 & OD1 & 6.525 \\
\hline 13 & Arg & 46 & $\mathrm{NH} 1$ & Asp & 55 & OD1 & 6.602 \\
\hline 14 & Arg & 46 & $\mathrm{NH} 2$ & Glu & 58 & OE1 & 7.955 \\
\hline 15 & Arg & 46 & $\mathrm{NH} 2$ & Glu & 58 & OE2 & 7.051 \\
\hline 17 & Glu & 205 & OE1 & Lys & 202 & $\mathrm{NZ}$ & 12.890 \\
\hline 18 & Glu & 205 & OE1 & Lys & 168 & $\mathrm{NZ}$ & 9.775 \\
\hline 19 & Glu & 205 & OE1 & Lys & 166 & $\mathrm{NZ}$ & 6.078 \\
\hline
\end{tabular}

\begin{tabular}{|c|ccc|ccc|c|} 
& & & & & & \\
21 & Glu & 205 & OE1 & His & 146 & NE2 & 7.744 \\
\hline 22 & Glu & 205 & OE2 & His & 146 & NE2 & 5.756 \\
\hline 23 & Glu & 205 & OE1 & His & 146 & ND1 & 5.750 \\
\hline 24 & Glu & 205 & OE2 & His & 146 & ND1 & 3.661 \\
\hline
\end{tabular}

\section{REFERENCES}

[1] R. De Vries, H. Kester, C. Poulsen, J. Benen, and J. Visser, "Synergy between accessory enzymes from Aspergillus in the degradation of plant cell wall polysaccharides," J. Carbohydr. Res., vol. 327, pp. 401-410, 2000.

[2] M. Numan and N. Bhosle, " $\alpha$-L-arabinofuranosidase: the potential applications in biotechnology," J. Ind Microbial Biotechnol, vol. 33, pp. 253, 2006.

[3] C. Vieille and G. Zeikus, "Hyperthermophillic Enzymes: Sources, Uses and Molecular Mechanisms for Thermostability," Microbiology and Molecular Biology Reviews, vol. 33, pp. 8, 2001.

[4] N. N. T. Puspaningsih, "Pencirian Enzim Xilanolitik dan Kloning Gen Penyandi Xilosidase dari Bacillus thermoleovorans IT-08," Ph.D Thesis, Sekolah Pascasarjana, Institut Pertanian Bogor, Bogor, Indonesia, 2004.

[5] M. Jonet, N. Mahadi, A. Murad, A. Rabu, F. D. Abu Bakar, K. O. Low, R. Illias, "Optimization of a Heterologous Signal Peptide by Site-Directed Mutagenesis for Improved Secretion of Recombinant Proteins in Escherichia coli," J Mol Microbiol Biotechnol, vol. 22, pp. 48-58, 2012.

[6] L. N. Yamani, "Konstruksi Sekresi Ekstraseluler dan Peningkatan pH Optimum $\alpha$-L-arabinofuranosidase dari Geobacillus thermoleovorans IT-08," Master Thesis, Departement of Chemistry, Faculty of Science and Technology, Universitas Airlangga, Surabaya, Indonesia, 2011.

[7] M. Berrondo, "Predicting The Structure and Function of Protein Mutants," Ph.D Thesis, John Hopkins University, Departement of Chemical and Biomolecular Engineering, United States of America, 2010 .

[8] N. Tokuriki, F. Stricher, J. Schymkowitz, L. Serrano, and D. Tawfik, "The Stability Effects of Protein Mutations Appear to Be Universally Distributed," J Mol Biol, pp. 1318, 2007.

[9] T. Schwede, J. Kopp, N. Guex, and M. Peitsch, "Swiss Model: An automated protein homology modeling server," Nucleic acid research, vol. 31 no. 13 pp. 3381-3381, 2003.

[10] K. Hovel, D. Shallom, K. Niefind, V. Belakhov, G. Shoham, T. Baasov, Y. Shoham, and D. Schomburg, "Crystal Structure and Snapshots Along The Reaction Pathway of A Family 51 $\alpha$-L-arabinofuranosidase," EMBO J., vol. 22, pp. 4922-4932, 2003.

[11] R. Maiti, H. Gary, G. V. Domselaar, H. Zhang, and D. Wishart, "SuperPose: a simple server for sophisticated structural superposition," Nucleic Acids Res., pp. 32, July 2004.

[12] E. Pettersen, T. Goddard, C. Huang, G. Couch, D. Greenblatt, E. Meng, and T. Ferrin, "UCSF Chimera--a visualization system for exploratory research and analysis," J Comput Chem., vol. 25, no. 13, pp. 1605-12, 2004.

[13] Y. Dehouck, A. Grosfils, B. Folch, D.Gillis, Ph. Bogaerts, and M. Rooman, "Prediction of protein stability changes upon mutations using statistical potentials and neural networks: PoPMuSiC 2.0," Bioinformatics, vol. 25, pp. 2537-2543, 2009.

[14] C. Bailey, L. Gerber, A. Howard, and S. Udenfriend, "Processing at the carboxyl terminus of nascent placental alkaline phospatase in a cell free system: Evidence for specific cleavage of a signal peptide," in Proc. Natl. Acad. Sci., USA, vol. 86, pp. 24, 1989.

[15] B. Westley and R. Weber, "Divergence of the two albumins of X.laevis: Evidence for the glycosylation of the major $74 \mathrm{~K}$ albumin," Differentiation, vol. 22, no. 3, pp. 227-30, 1982.

[16] E. Gasteiger, C. Hoogland, A. Gattiker, S. Duvaud, M. R. Wilkins, R. D. Appel, and A. Bairoch, "Protein Identification and Analysis Tools on the ExPASy Server," in The Proteomics Protocols Handbook, J. M. Walker, Ed., Humana Press, 2005, pp. 571-607.

[17] Y. Lu, K. Zen, S. Muthukrishnan, and K. Kramer, "Site-directed mutagenesis and functional analysis of active site acidic amino acid residues D142, D144 and E146 in Manduca sexta (tobacco hornworm) chitinase," Insect Biochemistry and Molecular Biology, vol. 32, pp. 1369-1382, 2002.

[18] J. Nielsen, T. Borchert, and G. Vriend, "The determinants of $\alpha$-amylase pH-activity profile," Protein Engineering, vol. 14 no. 7 pp. 505, 2001.

[19] B. Tynan-Connolly and J. Nielsen, "Redesigning protein pKa values," Protein Sci., 2007, vol. 16, no. 2, pp. 239. 
[20] N. Bogatyreva and D. Ivankov, "The Relationship between the Solvent-Accessible Surface Area of a Protein and the Number of Native Contacts in Its Structure," Molecular Biology, vol. 42, no. 6, pp. 932, 2008

[21] A. Lesk and C. Chotia, "Solvent Accessibility, Protein Surfaces and Protein Folding," Biophysical society, pp. 35, 1979.

[22] D. Whitford, Proteins Structure and Functions, West Sussex, England: John Wiley and Sons, Ltd., 2005, pp. 25, 28, 53-58.

[23] S. Kumar and R. Nussinov, "Close Range Electrostatic Interactions in Proteins," Chem Bio. Chem., vol. 3, no. 7, pp. 605, 2002.

[24] A. A. Karshikoff and I. Jelesarov, "Salt bridges and conformational flexibility: Effect on protein stability," Biotechnol and biotechnol, pp. 606, 2008.

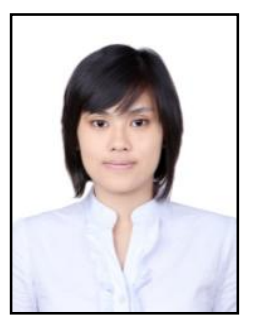

Ratna Melinda received the B.S. degree in biotechnology from Universitas Surabaya, Surabaya, Indonesia in 2010, and the M.S. degree in chemistry (biochemistry) from Universitas Airlangga, Surabaya, Indonesia in 2012.

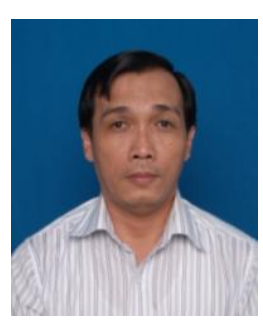

Handoko Darmokoesoemo received the B.S degree in chemistry from Universitas Airlangga, Surabaya, Indonesia in 1986, and the M.S. degree (DEA) in physical chemistry of bioinorganic from University of Louis Pasteur, Strasbourg, France in 1993.

From 1988 until now, he worked as a lecturer of physical chemistry in Faculty of Science and Technology, Airlangga University. From October 17, 2001 until December 15, 2001, he worked for Bilateral Program of the JSPS Scholarship Program concerning solid state NMR of anorganic material at Osaka University, Japan.

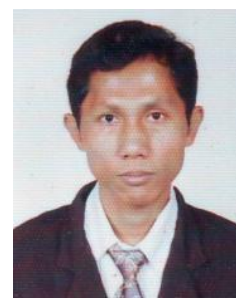

Purkan received the B.S. degree in 1991 at Department of Chemistry, Airlangga University, Surabaya, Indonesia, the M.Si. degree (1999) and Dr degree (2011) at Department of Chemistry, Institu Teknologi Bandung, Bandung, Indonesia. Since 1997 until now, he worked as a biochemistry lecturer at Department of Chemistry, Universitas Airlangga, Surabaya, Indonesia. He has a research interest about genomic and protein profiling especially in enzyme

and intracellular pathogenic protein of Mycobacterium tuberculosis. In this area, he works for construction of diagnostic kits and DNA as well as protein vaccine.

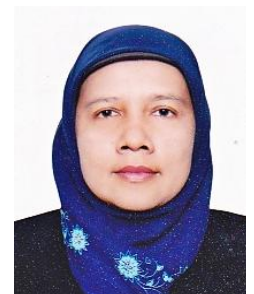

Ni Nyoman Tri Puspaningsih received the B.S. degree in chemistry from Department of Chemistry, Faculty of Mathematics and Natural Sciences, Universitas Airlangga, Surabaya, Indonesia in 1986 the M.Sc, degree from Department of Chemistry (Biochemistry) Faculty of Mathematics and Natural Sciences, Institut Teknologi Bandung, Indonesia in 1994, and the Doctorate degree from Department of Biology (Microbiology), Faculty of Mathematics and Natural Sciences, Institut Pertanian Bogor, Indonesia in 2004. She achieved the Professor title on 2010.

From 1987 to present, she worked as Biochemistry lecturer at Dept. of Chemistry, Faculty of Science and Technology in Universitas Airlangga. From 2011 to present, she works as the Head of Proteomic Laboratory at Institute of Tropical Disease in Universitas Airlangga. From 2007 to 2015 work as Director of Academic at Universitas Airlangga. On 1999, 2002 and 2003, she joined JSPS short course fellows in Japan. She joined post doctoral fellows program KNAW Netherlands on 2005 and 2007 at University of Groningen. Her current research interests include structure and function analysis of Xylanolytic enzymes from thermophilic bacteria.

Prof. Dr. Ni Nyoman Tri Puspaningsih, M.Si is the member of Indonesian Microbiology Society and Indonesian Protein Society. 